Journal of Telenursing (JOTING)

Volume 1, Nomor 2, Desember 2019

e-ISSN: 2684-8988

p-ISSN: 2684-8996

DOI: https://doi.org/10.31539/joting.v1i2.933

\title{
TERAPI AKTIVITAS SENAM ERGONOMIS TERHADAP PENINGKATAN KEMAMPUAN FUNGSIONAL LANSIA
}

\author{
Juli Andri ${ }^{1}$, Resi Karmila ${ }^{2}$, Padila ${ }^{4}$, Harsismanto. ${ }^{4}$, Andry Sartika ${ }^{5}$ \\ Universitas Muhammadiyah Bengkulu ${ }^{1,3,4,5}$
}

\begin{abstract}
ABSTRAK
Tujuan penelitian ini adalah untuk menganalisis pengaruh senam ergonomis terhadap peningkatan kemampuan fungsional pada lanjut usia di posyandu lansia wilayah kerja puskesmas sukamerindu kota bengkulu yang mengalami penurunan kemampuan fungsional. Desain penelitian ini menggunakan quasi eksperimental dengan rancangan pre test dan post test tanpa kelompok pembanding (kontrol). Hasil uji paired t-test menunjukkan terjadi peningkatan nilai kemampuan fungsional dengan $\mathrm{p}$ value $=0,000$ $<0,05$. Simpulan, terdapat pengaruh terapi aktivitas senam ergonomis terhadap peningkatan kemampuan fungsional pada lanjut usia.
\end{abstract}

Kata Kunci: Kemampuan Fungsional, Lanjut Usia, Senam Ergonomis

\section{ABSTRACT}

The purpose of this study was to analyze the effect of ergonomic exercise on the Improvement of Functional Ability in the elderly in the Posyandu Elderly Work Area of the Sukamerindu Public Health Center in Bengkulu City, which decreased Functional Ability. The design of this study used a quasi-experimental design with pre-test and post-test without comparison (control) groups. Paired T-test results showed an increase in the value of functional ability with $P$ Value $=0,000<0.05$. Conclusion, there is an influence of ergonomic exercise activity therapy on increasing functional ability in the elderly.

Keywords: Functional Ability, Elderly, Ergonomic Gymnastics

\section{PENDAHULUAN}

Permasalahan pada lansia dalam pemeliharaan kesehatan hanya 5\% yang di urus oleh institusi kesehatan dengan terapi nonfarmakologis, $25 \%$ adalah dengan terapi obatobatan. Akibatnya respon terhadap pengobatan kimia semakin meningkat, sehingga seorang lanjut usia lebih mudah terkena masalah kesehatan (Padila, 2013). Masalah kesehatan yang sering dialami meliputi kemunduran dan kelemahan baik kemunduran fisik, kognitif, perasaan, mental, dan sosial (Azizah, 2011).

Tahun 2012, di Asia jumlah absolut populasi lansia di atas 60 tahun terbesar adalah Cina (200 juta), India (100 juta) dan menyusul Indonesia (25 juta). Penduduk dianggap berstruktur tua di negara berkembang apabila penduduk usia 60 tahun ke atas sudah mencapai 7\% dari total penduduk. Tahun 2010 proporsi penduduk lansia di Indonesia telah mencapai sekitar 10\%. Indonesia seperti negara-negara lain di kawasan Asia Pasifik akan mengalami penuaan penduduk dengan amat sangat cepat. 
Diperkirakan Indonesia akan mencapai 100 juta lanjut usia (lansia) dalam tahun 2050. (Abikusno, 2013). Dilihat dari sebaran penduduk lansia menurut provinsi berdasarkan Susenas tahun 2012 Badan Pusat Statistik RI, jumlah penduduk lansia paling tinggi ada di Provinsi Yogyakarta dengan persentase 13,04\%, sedangkan Provinsi Bengkulu ada di urutan 20 dengan persentase 5,86\% (Pusat Data dan Informasi KemenKes RI, 2013).

Menua merupakan suatu proses menghilangnya secara perlahan-lahan (graduil) kemampuan jaringan untuk memperbaiki diri atau mengganti serta mempertahankan struktur dan fungsi secara normal, ketahanan terhadap cedera termasuk adanya infeksi. Proses penuaan sudah mulai berlangsung sejak seseorang mencapai dewasa, misalnya dengan terjadinya kehilangan jaringan pada otot, susunan syaraf dan jaringan lain sedikit demi sedikit. Tidak ada batasan yang tegas pada usia berapa kondisi kesehatan seseorang mulai menurun. Setiap orang memiliki fungsi fisiologis alat tubuh yang sangat berbeda, baik dalam pencapaian puncak fungsi tersebut maupun saat menurunnya. Fungsi fisiologis tubuh mencapai puncaknya pada usia 20-30 tahun. Setelah mencapai puncak, fungsi alat tubuh akan berada dalam kondisi tetap utuh beberapa saat, kemudian menurun sedikit demi sedikit sesuai dengan bertambahnya usia (Mubarak \& Wahit, 2011).

Lansia mengalami masalah kesehatan yang meliputi kemunduran dan kelemahan baik kemunduran fisik, kognitif, perasaan, mental, dan sosial (Azizah, 2011). fleksibilitas sendi pada lansia sehingga menimbulkan dampak berupa nyeri. Terjadi erosi pada kapsul persendian, sehingga akan menyebabkan penurunan luas dan gerak sendi, yang akan menimbulkan gangguan berupa pembengkakan dan nyeri (Azizah, 2011). Tubuh memiliki neuromodulator yang dapat menghambat transmisi impuls nyeri, salah satunya adalah beta-endorfin. Endorfin berperan untuk mengurangi sensasi nyeri dengan memblokir proses pelepasan substansi $\mathrm{p}$ dari neuron sensorik sehingga proses transmisi impuls nyeri di medula spinalis menjadi terhambat dan sensasi nyeri menjadi berkurang. Tingginya beta-endorfin juga memiliki dampak psikologis langsung yakni membantu memberi perasaan santai, mengurangi ketegangan, meningkatkan perasaan senang, membuat seseorang menjadi lebih nyaman, dan melancarkan pengiriman oksigen ke otot (Malo et al., 2019).

Terjadinya penurunan fungsi muskuloskeletal merupakan penyebab penting terjadinya proses penurunan kemampuan fungsional (Watson, 2003). Menurut Kresevic \& Mezey (2003) dalam Potter \& Perry (2009) status fungsional lansia biasanya merujuk pada kemampuan dan perilaku yang aman dalam aktivitas harian (ADL). Hal ini merupakan indikator yang sensitif bagi kesehatan atau penyakit pada lansia. Perubahan mendadak pada ADL merupakan tanda penyakit akut atau perburukan masalah kronis. Activity of daily living (ADL) adalah merupakan aktivitas pokok bagi perawatan diri (Tamher \& Noorkasiani, 2011).

Pada lansia juga terjadi perubahan pada kolagen, perubahan kolagen ini akan menjadi penyebab pada menurunnya fleksibilitas sendi pada lansia sehingga menimbulkan dampak berupa nyeri. Terjadi erosi pada kapsul persendian, sehingga akan menyebabkan penurunan luas dan gerak sendi, yang akan menimbulkan gangguan berupa pembengkakan dan nyeri (Azizah, 2011).

Penelitian yang dilakukan oleh Huriah et al., (2014) membuktikan bahwa terdapat pengaruh senam ergonomis terhadap penurunan skala nyeri sendi dan kekuatan otot pada lanjut usia di Wilayah Kerja Puskesmas Kasihan II Bantul Yogyakarta. 
Menurut Maryam \& Siti (2008) ada banyak cara untuk meningkatkan dan memelihara kebugaran, kesegaran dan kelenturan fisik lansia, seperti melakukan pekerjaan rumah dan berkebun, berjalan kaki, berenang serta senam, salah satu senam yang dapat dilakukan adalah senam ergonomis sebagai latihan senam setiap hari atau sekurang-kurangnya 2-3 kali seminggu. Senam ergonomis merupakan senam yang gerakan-gerakannya diadopsi dari gerakan sholat sehingga relatif mudah diikuti oleh lansia. Senam ergonomis merupakan senam fundamental yang gerakannya sesuai dengan susunan dan fungsi fisiologis tubuh. Tubuh dengan sendirinya terpelihara homeostatisnya (keteraturan dan keseimbangannya) sehingga tetap dalam keadaan bugar. Gerakan-gerakan ini juga memungkinkan tubuh mampu mengendalikan, menangkal beberapa penyakit dan gangguan fungsi sehingga tubuh tetap sehat (Sagiran, 2012).

Berdasarkan hasil survey awal yang peneliti lakukan pada beberapa Puskesmas di kota Bengkulu, Posyandu yang aktif dan jumlah lansia terbanyak yang mengikuti posyandu ada di Posyandu lansia wilayah kerja Puskesmas Sukamerindu. Wilayah Kerja Puskesmas Sukamerindu mempunyai jumlah lanjut usia sebanyak 1,032 jiwa dan merupakan urutan ke empat dari seluruh wilayah kerja puskesmas di Kota Bengkulu (DinKes, 2013). Hasil wawancara singkat yang peneliti lakukan dari 10 orang lansia 7 diantaranya mengalami penurunan pada kemampuan fungsional. Tujuan penelitian ini untuk menganalisis pengaruh senam ergonomis terhadap peningkatan kemampuan fungsional pada lanjut usia di posyandu lansia wilayah kerja puskesmas sukamerindu kota bengkulu yang mengalami penurunan kemampuan fungsional, selain itu lansia yang mengalami kemampuan fungsional di posyandu lansia belum mengenal senam ergonomis.

\section{METODE PENELITIAN}

Penelitian ini merupakan penelitian kuantitatif dengan desain quasi eksperimental dengan rancangan pretest and posttest tanpa kelompok kontrol, yaitu penelitian tanpa kelompok kontrol. Efektifitas perlakuan dinilai dengan cara membandingkan nilai post test dengan nilai pre test.

\section{Populasi dan Sampel Populasi}

Populasi pada penelitian ini adalah seluruh lansia yang mengikuti posyandu lansia di Wilayah Kerja Puskesmas Sukamerindu Kota Bengkulu yaitu 25 orang.

\section{Sampel}

Pengambilan sampel dalam penelitian ini di ambil secara Purposive Sampling. Sampel dalam penelitian ini adalah 15 orang, dengan kriteria Inklusi, yaitu mengalami gangguan kemampuan fungsional, berusia > 59 tahun, dapat mendengar dan melihat, bersedia menjadi responden dan dapat mengikuti prosedur penelitian sampai dengan tahap akhir, tidak memiliki penyakit yang menyebabkan responden sulit bergerak/ sulit untuk mengikuti prosedur senam ergonomis (seperti: stroke), dapat melakukkan minimal $80 \%$ prosedur gerakan senam ergonomis dan kooperatif. Sedangkan kriteria eksklusi dalam penelitian ini adalah lansia yang tidak kooperatif yaitu tidak mengikuti kegiatan secara penuh, lansia yang sedang menggunakan obat-obatan sedatif-hipnotif, 
lansia yang memiliki penyakit stroke sehingga tidak dapat bergerak, demensia, gangguan jiwa dan lansia yang lumpuh.

\section{Analisis Data}

Analisis data yang digunakan dalam penelitian ini adalah analisa univariat untuk mengetahui karakteristik lansia (umur), kemampuan fungsional sebelum diberi intervensi senam ergonomis dan sesudah diberi intervensi senam ergonomis. Pada analisis bivariat digunakan uji statistik paired t test.

\section{HASIL PENELITIAN}

Analisis Univariat

Tabel. 1

Identitas Responden Berdasarkan

Kelompok Usia $(n=15)$

\begin{tabular}{ccc}
\hline Usia & Frekuensi & Persentase \\
\hline 60-65 tahun & 12 responden & $80,0 \%$ \\
66-70 tahun & 3 responden & $20,0 \%$ \\
$>70$ tahun & - & - \\
Total & 15 Responden & $100,0 \%$ \\
\hline
\end{tabular}

Berdasarkan tabel 1 menunjukkan bahwa terdapat 12 orang responden $(80,0 \%)$ berusia antara 60-65 tahun dan 3 responden $(20,0 \%)$ berusia antara 66-70 tahun.

Tabel. 2

Distribusi Frekuensi Nilai Kemampuan Fungsional

Hasil Pre Test pada Responden

\begin{tabular}{ccc}
\hline Pre Test & Frekuensi & Presentase \\
\hline 10 & 1 & $6,7 \%$ \\
11 & 6 & $40,0 \%$ \\
12 & 8 & $53,3 \%$ \\
Total & 15 & $100,0 \%$ \\
\hline
\end{tabular}

Berdasarkan tabel 2 dapat diketahui bahwa hasil pre test nilai kemampuan fungsional lansia dengan menggunakan Kuesioner Katz Indeks yang telah dimodifikasi yaitu nilai kemampuan fungsional 10 sebanyak 1 orang $(6,7 \%)$, nilai kemampuan fungsional 11 sebanyak 6 orang $(40 \%)$ dan nilai kemampuan fungsional 12 sebanyak 8 orang $(53,3 \%)$.

Tabel. 3

Distribusi Frekuensi Nilai Kemampuan Fungsional Hasil Post Test pada Responden

\begin{tabular}{ccc}
\hline Post Test & Frekuensi & Presentase \\
\hline 12 & 1 & $6,7 \%$ \\
13 & 7 & $46,7 \%$ \\
14 & 5 & $33,3 \%$ \\
15 & 2 & $13,3 \%$ \\
\hline Total & 15 & $100,0 \%$ \\
\hline
\end{tabular}


Berdasarkan tabel 3 dapat diketahui bahwa hasil post test nilai kemampuan fungsional lansia degan menggunakan Kuesioner Katz Indeks yang telah dimodifikasi yaitu nilai kemampuan fungsional 12 sebanyak 1 orang $(6,7 \%)$, nilai kemampuan fungsional 13 sebanyak 7 orang (46,7\%), nilai kemampuan fungsional 14 sebanyak orang $(33,3 \%)$ dan nilai kemampuan fungsional 15 sebanyak 2 orang $(13,3 \%)$.

Tabel. 4

Perbedaan Nilai Kemampuan Fungsional Hasil Pre Test dan Post Test pada Responden Setelah Dilakukan Intervensi Senam Ergonomis

\begin{tabular}{lccc}
\hline \multicolumn{1}{c}{ Variabel } & Min-Max & SD & P value \\
\hline $\begin{array}{l}\text { Nilai Kemampuan Fungsional } \\
\text { sebelum intervensi }\end{array}$ & $10-12$ & 0,640 & \\
\cline { 1 - 2 } $\begin{array}{l}\text { Nilai Kemampuan Fungsional } \\
\text { sesudah intervensi }\end{array}$ & $12-15$ & 0,834 & 0,000 \\
\hline
\end{tabular}

Berdasarkan tabel 4 dapat diketahui bahwa 15 responden sebelum diberi intervensi senam ergonomis mengalami penurunan kemampuan fungsional $<13$, namun setelah diberikan intervensi mereka mengalami peningkatan nilai kemampuan fungsional.

\section{Analisis Bivariat}

Analisis yang digunakan untuk menganalisis pengaruh dua variabel dalam penelitian ini adalah pengaruh intervensi senam ergonomis terhadap kemampuan fungsional pada lanjut usia dapat dilihat pada tabel berikut ini :

Tabel. 5

Distribusi Rata-Rata Kemampuan Fungsional Responden Berdasarkan Hasil Pre Test dan Post Test Intervensi Senam Ergonomis

\begin{tabular}{lccccc}
\hline \multicolumn{1}{c}{ Variabel } & Mean & SD & SE & P Value & N \\
\hline Peningkatan Nilai Kemampuan & & & & & \\
Fungsional & 11,47 & 0,640 & 0,165 & 0,000 & \\
Pre Test Responden & 13,53 & 0,834 & 0,215 & & \\
Post Test Responden & & & & & \\
\hline
\end{tabular}

Berdasarkan tabel 5 rata-rata nilai kemampuan fungsional responden sebelum intervensi adalah 11,47 dengan standar deviasi 0,640 sedangkan rata-rata kemampuan fungsional responden setalah diberi intervensi adalah 13,53 dengan standar deviasi 0,834. Hasil uji statistik Uji t didapatkan nilai $\mathrm{P}$ value $=0,000(\mathrm{P}<\alpha=0,05)$, maka dapat disimpulkan ada pengaruh yang bermakna antara sebelum diberi intervensi dan setelah diberi intervensi senam ergonomis terhadap nilai kemampuan fungsional pada lanjut usia di posyandu lansia wilayah kerja Puskesmas Sukamerindu Kota Bengkulu. 


\section{PEMBAHASAN}

\section{Gambaran Distribusi Frekuensi Karakteristik Responden Berdasarkan Kelompok Usia}

Umur lansia dikelompokkan menjadi 3 kategori, yaitu 60-65 tahun, 66-70 tahun dan $>70$ tahun. Hasil penelitian menunjukkan bahwa terdapat 12 orang responden (80\%) berusia antara 60-65 tahun, 3 responden (20\%) berusia antara 66-70 tahun dan tidak ada responden yang berusia lebih dari 70 tahun. Nilai skor peningkatan kemampuan fungsional yang lebih signifikan terdapat pada kategori umur 60-65 tahun karena terdapat 3 orang responden terjadi peningkatan 3 skor lebih besar dari skor sebelumnya sedangkan pada kategori umur 66-70 tahun hanya terjadi peningkatan 2 skor dari sebelumnya.

\section{Gambaran Distribusi Frekuensi Nilai Kemampuan Fungsional Responden Hasil Pre Test}

Berdasarkan hasil pre test analisis univariat didapatkan hasil dari 15 responden dengan nilai kemampuan fungsional 10 ada 1 orang (6,7\%), nilai kemampuan fungsional 11 ada 6 orang $(40 \%)$ dan nilai kemampuan fungsional 12 ada 8 orang $(53,3 \%)$.

Hal ini menandakan bahwa kemampuan fungsional lansia akan mengalami gangguan seiring dengan pertambahan usia. Hal ini disebabkan karena pertambahan usia seseorang berpengaruh terhadap fungsi organ tubuh setelah mencapai puncak kematangan usia dewasa fungsi organ tubuh mengalami penurunan. Penurunan kemampuan melakukan aktifitas dan kemampuan kerja menjadi menurun. Penurunan tersebut karena penyusutan jaringan tubuh secara bertahap, yang meliputi jaringan otot, sistem syaraf, dan organ-organ vital lainnya. Hal ini didukung oleh Fatimah (2010) lansia yang karena usianya akan mengalami perubahan biologis, fisik serta kejiwaan.

\section{Gambaran Distribusi Frekuensi Nilai Kemampuan Fungsional Responden Hasil Post Test}

Berdasarkan hasil post test dapat diketahui bahwa hasil post test nilai kemampuan fungsional lansia degan menggunakan Kuisioner Katz Indeks yang telah dimodifikasi yaitu Nilai kemampuan fungsional 12 sebanyak 1 orang $(6,7 \%)$, nilai kemampuan fungsional 13 sebanyak 7 orang (46,7\%), nilai kemampuan fungsional 14 sebanyak 5 orang $(33,3 \%)$ dan nilai kemampuan fungsional 15 sebanyak 2 orang $(13,3 \%)$.

Pemberian senam ergonomis pada lansia yang mengalami penurunan kemampuan fungsional dilakukan 20 menit sebanyak 8 kali 2 kali dalam seminggu. Hasil penelitian menunjukkan bahwa semua responden mengalami peningkatan nilai kemampuan fungsional walaupun beberapa lansia hanya mengalami peningkatan 1 skor dari skor sebelumnya. Hal ini didukung Maryam \& Siti (2008) yang mengemukakan bahwa melakukan senam secara teratur dan benar dalam jangka waktu yang cukup dapat mempertahankan dan meningkatkan taraf kesegaran jasmani yang baik.

\section{Gambaran Perbedaan Nilai Kemampuan Fungsional Responden Sebelum dan Setelah Diberi Intervensi Senam Ergonomis}

Sebelum diberikan intervensi senam ergonomis pada lansia, peneliti melakukan pengkajian kemampuan fungsional menggunakan kuesioner Katz Indeks yang telah dimodifikasi. Kuesioner Katz Indeks meliputi 6 komponen kemampuan fungsional yaitu, makan, kontinen (BAB dan BAK), berpindah, ke kamar kecil, mandi dan 
berpakaian. Setiap pertanyaan memiliki nilai 0 sampai 1 . Nilai katz indeks terendah adalah 0 dan nilai Katz Indeks tertinggi adalah 17.

Hasil nilai penilaian kemampuan fungsional lansia ini berbeda-beda antara masing-masing responden. Menurut hasil penelitian paling banyak lansia mengeluh nyeri pada sendi dan otot sehingga kesulitan dalam melakukan aktivitas sehari-hari. Hal tersebut sesuai dengan apa yang dikemukakan Watson (2003) penyebab penting terjadinya penurunan kemampuan fungsional lansia disebabkan oleh terjadinya penurunan pada fungsi muskuloskeletal.

Pemberian senam ergonomis pada lansia yang mengalami penurunan kemampuan fungsional dilakukan 20 menit sebanyak 8 kali dan dilakukan 2 kali dalam seminggu. Hasil penelitian menunjukkan bahwa semua responden mengalami peningkatan nilai kemampuan fungsional walaupun beberapa lansia hanya mengalami peningkatan 1 skor dari skor sebelumnya. Hal ini didukung Maryam \& Siti (2008) yang mengemukakan bahwa melakukan senam secara teratur dan benar dalam jangka waktu yang cukup dapat mempertahankan dan meningkatkan taraf kesegaran jasmani yang baik.

Senam ergonomis mampu mengembalikan posisi dan kelenturan sistem saraf dan aliran darah. Memaksimalkan suplai oksigen ke otak, mampu menjaga sistem kesegaran tubuh, serta sistem pembuangan energi negatif dari dalam tubuh. Selain itu juga dapat meningkatkan kekuatan otot, efektifitas fungsi jantung, mencegah pengerasan pembuluh darah arteri, serta melancarkan sistem pernafasan. Senam ini bisa dilakukan oleh semua umur, senam ini juga terdiri dari gerakan sholat, sehingga lansia mudah mengaplikasikan gerakan senam ini (Sagiran, 2013; Oktaviani et al., 2018).

\section{Pengaruh Intervensi Senam Ergonomis terhadap Peningkatan Kemampuan Fungsional pada Lanjut Usia}

Berdasarkan hasil analisis bivariat pengaruh pemberian senam ergonomis terhadap kemampuan fungsional pada lanjut usia, diketahui hasil uji statistik dengan uji $\mathrm{T}$ menggunakan SPSS 16, didapatkan nilai yang signifikan yaitu dengan $\mathrm{P}$ value = $0,000<\alpha 0,05$ yang berarti Ho ditolak sehingga dapat disimpulkan bahwa ada pengaruh yang signifikan antara pemberian senam ergonomis terhadap peningkatan kemampuan fungsional pada lanjut usia di posyandu lansia wilayah kerja Puskesmas Sukamerindu Kota Bengkulu.

Hal tersebut sesuai dengan yang dikemukakan Sagiran (2012) bahwa dengan rutin melakukan senam ergonomis setiap hari atau sekurang-kurangnya 2 kali dalam seminggu maka akan dapat menangkal beberapa penyakit dan gangguan fungsi organ lainnya sehingga tubuh tetap sehat.

Lansia mengalami masalah kesehatan yang meliputi kemunduran dan kelemahan baik kemunduran fisik, kognitif, perasaan, mental, dan sosial (Azizah, 2011). fleksibilitas sendi pada lansia sehingga menimbulkan dampak berupa nyeri. Terjadi erosi pada kapsul persendian, sehingga akan menyebabkan penurunan luas dan gerak sendi, yang akan menimbulkan gangguan berupa pembengkakan dan nyeri (Azizah, 2011). Tubuh memiliki neuromodulator yang dapat menghambat transmisi impuls nyeri, salah satunya adalah beta-endorfin. Endorfin berperan untuk mengurangi sensasi nyeri dengan memblokir proses pelepasan substansi p dari neuron sensorik sehingga proses transmisi impuls nyeri di medula spinalis menjadi terhambat dan sensasi nyeri menjadi berkurang. Tingginya beta-endorfin juga memiliki dampak psikologis langsung yakni membantu memberi perasaan santai, mengurangi ketegangan, meningkatkan perasaan 
senang, membuat seseorang menjadi lebih nyaman, dan melancarkan pengiriman oksigen ke otot (Malo et al., 2019).

Beberapa terapi yang dapat dilakukan untuk mengurangi rasa nyeri pada lansia antara lain farmakoterapi (terapi yang paling sering digunakan), dukungan psikologis, rehabilitasi fisik, dan prosedur intervensi. Terapi farmakologis yang sering digunakan antara lain NSAID, relaksan otot, opioid, dan terapi adjuvan (Kaye, 2010). Terapi non farmakoterapi merupakan komponen multimodal manajemen yang sangat penting karena membantu dalam mengatasi nyeri yang lebih baik dengan perbaikan dalam fungsi sehari-hari, di dalamnya termasuk terapi fisik (Rastogi \& Meek, 2013). Pemberian terapi farmakologis memiliki risiko tinggi menghasilkan efek yang kurang baik bagi kesehatan lansia dengan berbagai penurunan fungsi tubuh maka terapi non farmakologis seperti pemberian aktivitas olahraga fisik ini menjadi alternatif terbaik untuk mengatasi nyeri lansia (Capezuti et al., 2008).

Senam ergonomik atau senam Inti Prima Raga adalah teknik senam untuk mengembalikan atau membetulkan posisi dan kelenturan sistem saraf dan aliran darah, memaksimalkan asupan oksigen ke otak, membuka sistem kecerdasan,sistem muskuloskeletal, sistem keringat, sistem pemanasan tubuh, sistem pembakaran asam urat, kolestrol, gula darah, asam laktat, kristal oksalet, sistem konversi karbohidrat, sistem pembuatan elektrolit atau ozon dalam darah, sistem kekebalan tubuh (Wratsongko, 2015).

Sedangkan senam ergonomik adalah senam fundamental yang gerakannya sesuai dengan susunan dan fisiologis tubuh. Tubuh dengan sendirinya terpelihara homeostatisnya (keteraturan dan keseimbangannya) sehingga tetap dalam keadaan bugar (Sagiran, 2013).

Senam ergonomis sendiri untuk mengendalikan atau membetulkan posisi dan kelenturan sistem saraf pada aliran darah, memaksimalkan suplai darah ke oksigen ke otak, dapat membuka sistem kecerdasan, sistem keringat, sistem pemanas tubuh, sistem pembakaran pada asam urat, kolestrol, gula darah, asam laktat, sistem konversi karbohidrat dan sistem pembuangan energi negraif pada tubuh. Senam ergonomis terdapat gerakan yang sangat efektif, efesien, dan logis, karena pada rangkaian gerakanannya merupakan rangkaian gerak yang bisa dilakukan manusia sejak dulu sampai saat ini (Wratsongko, 2015).

Gerakan-gerakan senam ergonomis sesuai dengan kaidah-kaidah penciptaan tubuh yang terkait dengan gerakan sholat, artinya senam ergonomis yang langsung dapat membuka, membersihkan, dan mengaktifkan seluruh sistem- sistem tubuh seperti sistem kardiovaskuler, kandung kemih, dan sistem reproduksi.Oleh karena itu apabila gerakan ini dilakukan secara rutin akan berguna untuk membentuk daya tahan tubuh yang optimal, khususnya bagi seorang yang mengalami lanjut usia (Wratsongko, 2015).

\section{SIMPULAN}

Dari hasil penelitian yang peneliti lakukan tentang Pengaruh Terapi Aktivitas Senam Ergonomis Terhadap Kemampuan Fungsional Lansia di Posyandu Lansia Wilayah Kerja Puskesmas Sukamerindu Kota Bengkulu didapatkan kesimpulan:

Identitas responden di Posyandu Lansia Wilayah Kerja Puskesmas Sukamerindu berdasarkan usia, yaitu sebagian besar berusia antara 60-65 tahun.

Distribusi nilai kemampuan fungsional sebelum diberi intervensi Senam Ergonomis dengan menggunakan Kuesioner Katz Indeks memiliki nilai minimal 10, maksimal 12. Distribusi nilai kemampuan fungsional setelah diberi intervensi Senam 
Ergonomis dengan menggunakan Kuesioner Katz Indeks memiliki nilai minimal 12, maksimal 15.

Terdapat perbedaan nilai kemampuan fungsional pada lansia sebelum dan setelah diberi intervensi Senam Ergonomis. Terdapat pengaruh terapi aktivitas senam ergonomis terhadap peningkatan kemampuan fungsional lansia.

\section{SARAN}

\section{Bagi Layanan dan Masyarakat}

Senam ergonomis dapat dijadikan kegiatan rutin bagi lansia untuk memperbaiki kekuatan otot yang menurun dan meningkatkan derajat kesehatan.

Hasil penelitian ini dapat diaplikasikan oleh masyarakat untuk mengintervensi kemampuan fungsional yang menurun dan meningkatkan derajat kesehatan.

\section{Bagi Pendidikan Keperawatan}

Menggalakkan program kerjasama dengan lahan pelayanan kesehatan dalam rangka mengembangkan praktek keperawatan yang berbasis non-farmakologi.

Penelitian ini dapat dipublikasikan secara luas sehingga dapat dijadikan sumber referensi untuk menambah kajian tentang terapi non-farmakologi untuk meningkatkan kemampuan fungsional serta meningkatkan derajat kesehatan.

Hasil penelitian ini dapat dijadikan landasan atau bahan kajian untuk mengembangkan penelitian lebih lanjut mengenai tindakan kesehatan dalam meningkatkan kemampuan fungsional. Dan dapat dilakukan penelitian lanjutan tentang senam ergonomis pada variabel lain.

\section{DAFTAR PUSTAKA}

Abikusno, N. (2013). Kelanjutusiaan Sehat Menuju Masyarakat Segala Usia. Jakarta: Buletin Jendela data dan Informasi Kesehatan

Azizah. L. M. (2011). Keperawatan Lanjut Usia. Yogyakarta: Graha Ilmu

Capezuti, E. A., Siegler, E. L., \& Mezey, M. D. (2008). The Encyclopedia of Elder Care: the Comprehensive Resource on Geriatric and Social Care, 2nd edition. New York, USA: Springer, pp. 429-432

Dinkes. (2013). Cakupan Pelayanan Kesehatan Usia Lanjut Menurut Jenis Kelamin, Kecamatan dan Puskesmas Kota Bengkulu. Bengkulu: Dinkes

Fatimah, F. (2010). Merawat Lanjut Usia Suatu Pendekatan Proses Keperawatan Gerontik. Jakarta: Trans Info Media

Huriah, T., Ema W., Afiani, S. R., \& Yuliana M. M. (2014). Pengaruh Senam Ergonomis terhadap Penurunan Skala Nyeri Sendi dan Kekuatan Otot pada Lanjut Usia di Wilayah Kerja Puskesmas Kasihan II Bantul Yogyakarta. Manuskrip Penelitian, Universitas Muhammadiyah Yogyakarta. http://mkep.umy.ac.id/wp-content/uploads/2016/02/Manuskrip- Riset-AIPNI SERGO-2014-Titih.pdf

Kaye, B. S. (2010). Pain Management in the Elderly Population: A Review. The Ochsner Journal, 10, 179-187

Kemenkes RI. (2013). Gambaran Kesehatan Lanjut Usia di Indonesia. Jakarta: Kemenkes RI http//www.kemenkes-RI-buletin-lansia.pdf

Malo, Y., Ariani, N. L., \& Yasin, D. D. F. (2019). Pengaruh Senam Ergonomis terhadap Skala Nyeri Sendi pada Lansia Wanita. Nursing News, 4(1), 190-199 
Maryam, R., \& Siti, S. (2008). Mengenal Usia Lanjut dan Perawatannya. Jakarta: Salemba Medika

Mubarak, M., \& Wahit, I. (2011). Ilmu Keperawatan Komunitas 2. Jakarta: Salemba Medika

Oktaviyani, R. D., Hartono, A., \& Putri, M. A. (2018). Efektifitas Senam dan Senam Ergonomis terhadap Perubahan Skala Insomnia pada Lansia di UPT Pelayanan Sosial Lanjut Usia Magetan. STIKES Bhakti Husada Mulia Madiun

Padila, P. (2013). Buku Ajar Keperawatan Gerontik. Yogyakarta: Nuha Medika

Potter, P., \& Perry, P. (2009). Fundamental Keperawatan. Jakarta: Salemba Medika

Rastogi, R., \& Meek, M. (2013). Management of Chronic Pain in Elderly, Frail Patients: Finding a Suitable, Personalized Method of Control. Dove Medical Press Ltd

Sagiran, S. (2012). Mukjizat Gerakkan Shalat. Jakarta: Qultum Media

Sagiran, S. (2013). Mukjizat Gerakan Sholat. Jakarta: Qultum Media

Tamher, S., \& Noorkasiani. (2011). Kesehatan Usia Lanjut dengan Pendekatan Asuhan Keperawatan. Jakarta: Salemba Medika

Watson. R. (2003). Perawatan pada Lanjut Usia. Jakarta: EGC

Wratsongko, M. M. M. (2015). Mukjizat Gerakan Shalat \& Rahasia 13 Unsur Manusia. Jakarta 